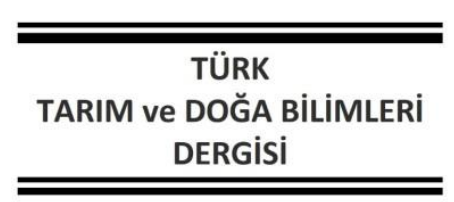

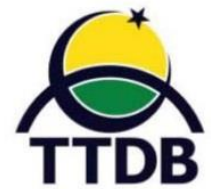

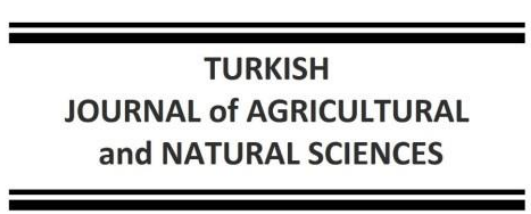

www.dergipark.gov.tr/turkjans

Research Article

\title{
Antioxidant Defense System in Borago officinalis L. under Drought Stress
}

\author{
Hülya TORUN ${ }^{1 *}$, Engin EROĞLU² \\ ${ }^{1}$ Department of Biosystem Engineering, Faculty of Agriculture, Düzce University, Düzce, Turkey \\ ${ }^{2}$ Department of Landscape Architecture, Faculty of Forestry, Düzce University, Düzce, Turkey \\ *Corresponding author: hulyatorun@duzce.edu.tr
}

Received: 08.06.2021 Received in revised: 13.09.2021 Accepted: 14.10.2021

\begin{abstract}
Drought is one of the main abiotic stress factor that limits plant growth and development. Drought stress effects on Borago officinalis L. (borage) plants in terms of physiological and antioxidant responses have been evaluated in this study. In parallel with this purpose, relative growth rate (RGR), leaf relative water content (RWC), osmotic potential, chlorophyll fluorescence (Fv/Fm), lipid peroxidation, hydrogen peroxide $\left(\mathrm{H}_{2} \mathrm{O}_{2}\right)$ level, superoxide dismutase (SOD), peroxidase (POX), catalase (CAT), ascorbate peroxidase (APX) and glutathione reductase (GR) activities were determined under drought treatment in a controlled greenhouse. RGR, RWC and osmotic potential were significantly decreased, while lipid peroxidation expressed thiobarbutiric acid reactive substances (TBARS) and $\mathrm{H}_{2} \mathrm{O}_{2}$ contents were increased under drought stress. On the other hand, significant increases in POX, CAT, APX and GR activities did not prevent the increase in lipid peroxidation. To the best of our knowledge, this is the first study conducted on the enzymatic antioxidants of the defense system of Borago officinalis L. under drought stress.
\end{abstract}

Key words: Antioxidant enzymes, borage, drought, oxidative stress, reactive oxygen species

\section{Kuraklık Stresi Altında Borago officinalis L.'de Antioksidan Savunma Sistemi}

Öz Kuraklık, bitki büyümesini ve gelişmesini sınırlayan temel abiyotik stres faktörlerinden biridir. Bu çalışmada, kuraklık stresinin Borago officinalis (hodan) bitkisi üzerindeki fizyolojik ve antioksidan tepkileri açısından etkileri değerlendirilmiştir. Bu amaç doğrultusunda, bağıl büyüme oranı (RGR), yaprak bağı su içeriği (RWC), ozmotik potansiyel, klorofil floresansı (Fv/Fm), lipid peroksidasyonu, hidrojen peroksit $\left(\mathrm{H}_{2} \mathrm{O}_{2}\right)$ düzeyi, süperoksit dismutaz (SOD), peroksidaz (POX) , katalaz (CAT), askorbat peroksidaz (APX) ve glutatyon redüktaz (GR) aktiviteleri kontrollü bir serada kuraklık uygulaması altında belirlendi. RGR, RWC ve ozmotik potansiyel önemli ölçüde azalırken, tiyobarbutirik asit reaktif maddeleri (TBARS) olarak ifade edilen lipid peroksidasyonu ve $\mathrm{H}_{2} \mathrm{O}_{2}$ içerikleri kuraklık stresi altında arttı. Diğer taraftan, POX, CAT, APX ve GR aktivitelerindeki önemli artışlar lipid peroksidasyonundaki artışı engelleyemedi. Bildiğimiz kadarıyla bu çalışma, Borago officinalis'in enzimatik antioksidan savunma sistemi üzerine kuraklık stresi altında yapılan ilk çalışmadır.

Anahtar kelimeler: Antioxidant enzimler, hodan, kuraklık, oksidatif stres, reaktif oksijen türler

\section{Introduction}

Drought is one of the main restrictive abiotic stress factor limiting plant growth and yield particularly in arid and semiarid regions (Zhou et al., 2007). Membrane integrity, transpiration, water use efficiency, photosynthetic activity, respiration and several physiological periods were affected from seed germination to maturity by drought stress (Fracasso et al., 2016). The ability of the plants to initiate physical and biochemical processes determines survival capacity of them under drought. Drought stress causes oxidative damage in plants and leads to the production of reactive oxygen species (ROS) such as hydrogen peroxide $\left(\mathrm{H}_{2} \mathrm{O}_{2}\right)$, superoxide $\left(\mathrm{O}_{2}{ }^{--}\right)$and hydroxyl radical (OH) (Mattos and Moretti, 2015). To 
control the level of ROS under drought stress, plant cellular protective mechanisms including antioxidant enzymes and non-enzymatic antioxidants are activated for detoxifying of ROS (Mittler, 2002; Hasanuzzaman et al., 2020).

Borage (Borago officinalis L.; Boraginaceae) is an annual herbaceous plant and it is cultivated for its medicinal importance. Borage seed oil contains more than $20 \%$ gamma linolenic acid (Torabi et al., 2015). Most studies with borage were related to its chemical composition and antioxidant activity of leaves and flowers (Mohajer et al., 2016; Borowy et al., 2017; Zemmouri et al., 2019; Fernandes et al., 2019). On the other hand, the limited number of studies recorded with Borago officinalis under abiotic stress conditions. Salt stress (Jaffel et al., 2011; Torabi et al., 2015) and aluminum toxicity (Shahnaz et al., 2011) studies with borage have been reported in terms of the antioxidant response. Plant-pollinator interactions were also revealed under temperature and water stress (Descamps et al., 2018). However, the impact of drought stress on antioxidant defense system in borage plants have not been still conducted. To the best of our knowledge, this is the first study on ROS detoxification and antioxidative enzymes of this species under drought conditions.

Therefore, no data is available on the physiological and biochemical behavior of Borago officinalis under drought, the aim of this study was to examine the changes in the values of growth parameters, relative water content, osmotic potential, chlorophyll fluorescence, lipid peroxidation, hydrogen peroxide content and antioxidant enzyme activities such as SOD, POX, CAT, APX and GR of this species to drought.

\section{Material and Methods \\ Plant material and stress applications}

Borage (Borago officinalis L.) seeds were used in this study. The seeds were surface sterilized with $5 \%$ sodium hypochlorite and rinsed at least 5 times with deionised water for removing the bleach. After that, greenhouse experiments were carried out under controlled conditions $\left(27 / 22^{\circ} \mathrm{C}\right.$ day/night and $70 \%$ relative humidity). Seeds were sown in a pot containing organic media made of peat moss, perlite and sand (1:1:1). After two months of growing, drought stress was initiated and plants were not watered for two weeks for drought treatment. Plants irrigated every other day were considered as control plants. After 2-week drought period, $3^{\text {rd }}$ and $4^{\text {th }}$ fully opened leaves were harvested and frozen with liquid nitrogen $\left(-196^{\circ} \mathrm{C}\right)$ and stored at $-80^{\circ} \mathrm{C}$ until further analyses.
Determination of relative growth rate (RGR), relative water content (RWC), osmotic potential $\left(\Psi_{\mathrm{s}}\right)$ and chlorophyll fluorescence (Fv/Fm)

Five plants were used for each group. After the samples were dried $\left(70^{\circ} \mathrm{C}\right.$ for $\left.72 \mathrm{~h}\right)$, dry weights (DW) were measured. The RGR of leaves was calculated by using the following formula (Hunt et al., 2002):

$R G R=\left[\ln \left(D W_{\text {final }}\right)-\ln \left(D W_{\text {initial }}\right)\right] /\left(t_{\text {final }}-t_{\text {initial }}\right)$, where $\mathrm{DW}_{\text {final }}=$ dry weight $(\mathrm{g})$ at $\mathrm{t}_{\text {final }} ; \mathrm{DW}_{\text {initial }}=$ dry weight $(\mathrm{g})$ at $t_{\text {initial, }} t_{\text {initial; initial harvest time and }}$ $t_{\text {final; final harvest time. }}$

Five leaves from each group during the harvest were weighed and fresh weights (FW) were recorded. For turgid weight (TW) determination, leaves were put in water for $8 \mathrm{~h}$. After that, turgid leaves were dried $\left(70^{\circ} \mathrm{C}\right.$ for $\left.72 \mathrm{~h}\right)$ and dry weights (DW) were determined. RWC of leaves was calculated by using the following formula:

RWC $(\%)=((F W-D W) /(T W-D W)) \times 100$

Chlorophyll fluorescence and osmotic potential were measured according to the manufacturer's instructions. Five leaves from each group were used for analyses. Plant Efficiency Analyzer of Hansatech (UK) and Wescor Vapro Pressure Osmometer (5600) were utilized to measure the maximal quantum yield of PSII photochemistry (Fv/Fm) and osmotic potentail $\left(\Psi_{s}\right)$ of leaves, respectively.

\section{Determination of lipid peroxidation and $\mathrm{H}_{2} \mathrm{O}_{2}$ content}

Lipid peroxidation (TBARS) level were determined according to the method of Heath and Packer (1968). $0.5 \mathrm{~g}$ fresh leaves were extracted in $0.1 \%$ trichloroacetic acid (TCA) and then centrifuged at $12000 \mathrm{~g}$ for $15 \mathrm{~min}$ at $4^{\circ} \mathrm{C}$. $1 \mathrm{~mL}$ of supernatant was mixed with $4 \mathrm{~mL}$ of $20 \%$ TCA with $0.5 \%$ thiobarbituric acid. After $30 \mathrm{~min}$ at $95^{\circ} \mathrm{C}$, samples were cooled and the absorbance was recorded at 532 and $600 \mathrm{~nm}$.

$\mathrm{H}_{2} \mathrm{O}_{2}$ level were determined according to the method of (Liu et al., 2000). $0.5 \mathrm{~g}$ fresh leaves were extracted in 1\% TCA and then centrifuged at 12000 $\mathrm{g}$ for $15 \mathrm{~min}$ at $4^{\circ} \mathrm{C}$. $\mathrm{TiCl}_{4}$ solution prepared with $20 \% \mathrm{H}_{2} \mathrm{SO}_{4}$ was mixed with supernatant and the absorbance was recorded at $410 \mathrm{~nm}$.

\section{Antioxidant enzymes activity assays}

$0.5 \mathrm{~g}$ of fresh leaves for used protein and antioxidant enzyme extractions. Leaves were ground with liquid nitrogen and extracted ice-cold $50 \mathrm{mM}$ phosphate buffer ( $\mathrm{pH}$ 7.0) consisting $1 \mathrm{mM}$ ethylenediaminetetraacetic acid (EDTA) and 1\% polyvinylpyrrolidone. $2 \mathrm{mM}$ ascorbate was added to the buffer for APX activity assay. Samples were centrifuged at $14000 \mathrm{~g}$ for $30 \mathrm{~min}$. Supernatants 
were used for protein and enzyme activity assays. The protein content was detected with bovine serum albumin method (Bradford, 1976).

The procedure of Beauchamp and Fridovich (1971) was used for the activity of superoxide dismutase (SOD; EC.1.15.1.1). The reaction mixture contained $50 \mathrm{mM}$ phosphate buffer ( $\mathrm{pH} 7.0), 0.1 \mathrm{mM}$ EDTA, $13 \mathrm{mM}$ methionine, $0.075 \mathrm{mM}$ nitro blue tetrazolium and $2 \mu \mathrm{M}$ riboflavin and $50 \mu \mathrm{L}$ enzyme extract. The absorbance was recorded at $560 \mathrm{~nm}$. One unit of the activity was defined as the quantity of enzyme required to produce $50 \%$ inhibition of nitro blue tetrazolium. The procedure of Mika and Lüthje (2003) was used for the activity of peroxidase (POX; EC.1.11.1.7). The reaction mixture contained $25 \mathrm{mM}$ sodium acetate ( $\mathrm{pH}$ 5.0), $10 \mathrm{mM}$ guaiacol and $10 \mathrm{~mm} \mathrm{H} \mathrm{O}_{2}$. The absorbance was recorded at $470 \mathrm{~nm}$. One unit of the activity was defined as the amount required to decompose $1 \mu \mathrm{mol} \mathrm{H}_{2} \mathrm{O}_{2}$ per $\mathrm{min}^{-1}$. The procedure of Aebi (1984) was utilized for the activity of catalase (CAT; EC 1.11.1.6). The reaction mixture contained 50 $\mathrm{mM}$ phosphate buffer $(\mathrm{pH} 7.0)$ and $10 \mathrm{mM} \mathrm{H}_{2} \mathrm{O}_{2}$. The absorbance was recorded at $240 \mathrm{~nm}$. One unit of CAT activity was defined as the amount needed to decompose $1 \mu \mathrm{mol} \mathrm{H}_{2} \mathrm{O}_{2}$ per $\mathrm{min}^{-1}$. The procedure of Nakano and Asada (1981) was used for the ascorbate peroxidase (APX; EC 1.11.1.11) activity. The reaction mixture contained $50 \mathrm{mM}$ phosphate buffer (pH 7.0), $250 \mu \mathrm{M}$ ascorbate and 5 $\mathrm{mM} \mathrm{H} \mathrm{H}_{2}$. The absorbance was recorded at 290 $\mathrm{nm}$. One unit of APX was defined as the amount needed to oxidize $1 \mu \mathrm{mol}$ ascorbate per $\mathrm{min}^{-1}$. The procedure of Foyer and Halliwell (1976) was utilized for the glutathione reductase (GR; EC 1.6.4.2) activity. The reaction mixture contained 50 $\mathrm{mM}$ Tris- $\mathrm{HCl}$ buffer ( $\mathrm{pH}$ 7.6), $5 \mathrm{mM} \mathrm{NADPH}$ and 10 $\mathrm{mM}$ oxidized glutathione. The absorbance was recorded at $340 \mathrm{~nm}$. One unit of GR was defined as the amount required to reduce $1 \mu \mathrm{mol}$ oxidized glutathione per $\min ^{-1}$.

\section{Statistical analysis}

All experiments were repeated in six times, the results were evaluated using ANOVA and expressed as mean and error bars. Means were compared using the test of the minor differences of Fisher's Least Significant Difference (LSD) at a 95\% probability level.

\section{Results and Discussion}

Previous studies about Borago officinalis L. have focused on plant-pollinator interactions under temperature and water stress (Descamps et al., 2018), chemical composition and antioxidant activity in leaves (Borowy et al., 2017; Zemmouri et al., 2019), flowers (Mohajer et al., 2016; Borowy et al., 2017; Fernandes et al., 2019) and seeds (Borowy and Kapłan, 2020). Moreover, salt stress effects on growth, lipid peroxidation and antioxidant enzyme activities (Jaffel et al., 2011; Torabi et al., 2015) were also evaluated. However, ROS detoxifying and antioxidant defense system interactions are still need further explanation for this species under drought stress. So, in the present study, antioxidant defense system in terms of physiological and biochemical approaches under drought was studied in Borago officinalis.

Reduction in water content and growth are the first responses of abiotic stress conditions (Torun, 2019). Plant growth and yield are extremely negative affected by drought (Osakabe et al., 2014; Sun et al., 2020). In our study, RGR of borage was also significantly $(P<0.05)$ reduced by $20.8 \%$ under drought as compared to non-stressed plants (Figure 1A). This reduction can be also seen as morphologically in Figure 2. Similar to our results, the findings for cotton (Sekmen et al., 2014), tomato (Rady et al., 2020) and wheat (Hassan et al., 2020) support our remarks in terms of drought-induced reduction in plant dry matters. Drought stress also caused considerable $(P<0.05)$ reductions in Borago officinalis leaf RWC and osmotic potential by $40.7 \%$ and 2.4 -fold, respectively, but chlorophyll fluorescence remained unchanged as compared to control plants (Figure 1B, C, D). A possible reason of reduction in growth might be related the reduction of water uptake and loss of turgor under drought stress (Ings et al., 2013) as has been found in our study. Therefore, drought-induced reduction in borage water content is connected with dry weight reduction.

In many metabolic processes associated with abiotic stress, plants produce ROS which are highly reactive and would be scavenged along the way by the many antioxidative mechanisms (Mittler et al., 2002; Hasanuzzaman et al., 2020). Hydrogen peroxide $\left(\mathrm{H}_{2} \mathrm{O}_{2}\right)$ is one of ROS and excessive accumulation of $\mathrm{H}_{2} \mathrm{O}_{2}$ which caused an increase in TBARS content as an indicator of oxidative damage in membrane lipids (Amoah et al., 2019; Killi et al., 2020) was also recorded in the present study. In our observation, $\mathrm{H}_{2} \mathrm{O}_{2}$ and TBARS content increased by 2.1-fold and 75.9\%, respectively, in borage leaves under drought stress (Figure 3). Similar results in terms of high accumulation $\mathrm{H}_{2} \mathrm{O}_{2}$ accompanied with high lipid peroxidation were detected in Oryza sativa (Basu et al., 2010; Ozfidan-Konakci et al., 2015), Solanum lycopersicum (Rady et al., 2020) and Triticum aestivum (Hassan et al., 2020) under drought. High levels of $\mathrm{H}_{2} \mathrm{O}_{2}$ and TBARS positively correlated with growth and water content inhibition might be 
associated with drought sensitivity of Borago officinalis. Parallel to our findings, drought sensitive Gossypium hirsutum (Sekmen et al., 2014), Amaranthus tricolor (Sarker and Oba, 2018) and Triticum aestivum (Abid et al., 2018) showed similar results.

SOD is one of the antioxidant enzyme that dismutases $\mathrm{O}_{2}{ }^{--}$into $\mathrm{H}_{2} \mathrm{O}_{2}$ and reduces the possibility of ${ }^{\circ} \mathrm{OH}$ formation (Gill et al,. 2015). $\mathrm{H}_{2} \mathrm{O}_{2}$ generated by stress or dismutation activity must be scavenged antioxidant enzymes such as POX, CAT, APX or GR (Mittler, 2002; Ozfidan-Konakci et al., 2015). In our study SOD activity in Borago officinalis was reduced by $23.9 \%$ (Figure $4 \mathrm{~A}$ ), while $\mathrm{H}_{2} \mathrm{O}_{2}$ increased (2.1-fold) under drought stress (Figure 3A). SOD activity reduction observed in this study is in agreement with that of Basu and coworkers (2010) but not that of Abid et al. (2018). SOD activity reduction might be one of the reason of the strong oxidative stress in drought-treated borage plants. Moreover, accumulation of $\mathrm{H}_{2} \mathrm{O}_{2}$ due to SOD activity reduction under drought stress might be a function in oxidative stress signaling leading to the induction of peroxidase antioxidant systems (Basu et al., 2010). Furthermore, SOD activity is not only the source of $\mathrm{H}_{2} \mathrm{O}_{2}$ by scavenging of superoxide, but also glycolate oxidase activity in peroxisomes, $\beta$-oxidation of fatty acids in glyoxysomes, NADPH oxidase enzyme activity also lead to produce $\mathrm{H}_{2} \mathrm{O}_{2}$ in several compartments of plant cells (Mittler et al., 2002; Hasanuzzaman et al., 2020). On the other hand, drought stress considerably increased POX, CAT, APX and GR activities in Borago officinalis leaves and enhancement of these enzyme activities were detected by 8-, 4.1-, 11- and 2.3-fold, respectively (Figure 4B, C, D, E). Although high activities of POX, CAT, APX and GR were connected to with the efficient scavenging of $\mathrm{H}_{2} \mathrm{O}_{2}$ under drought stress (Basu et al., 2010; Ozfidan-Konakci et al., 2015), antioxidant defense in drought-treated Borago officinalis might be insufficient in terms of increase in lipid peroxidation on membranes and reduction in water content and growth as can be seen morphologically (Figure 2).
A)

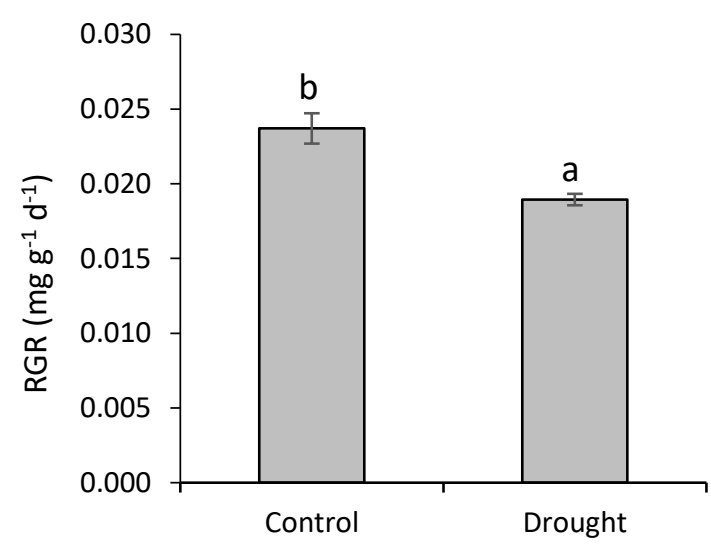

C)

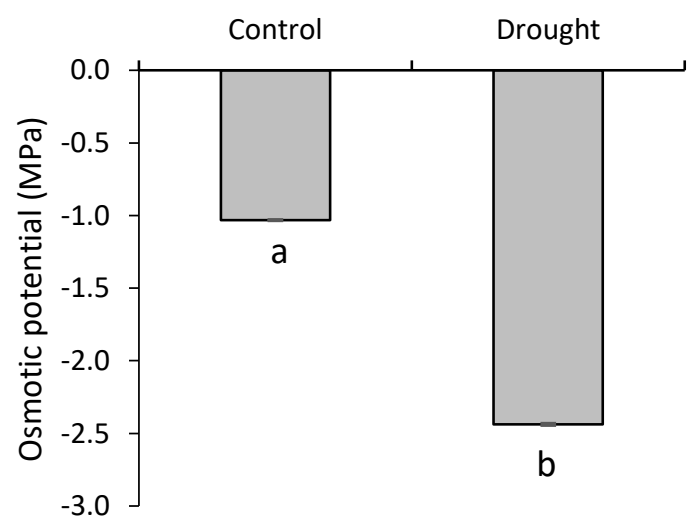

B)

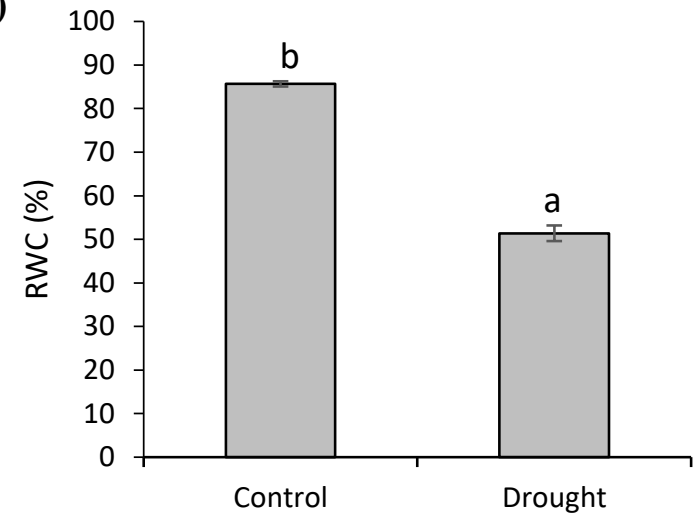

D)

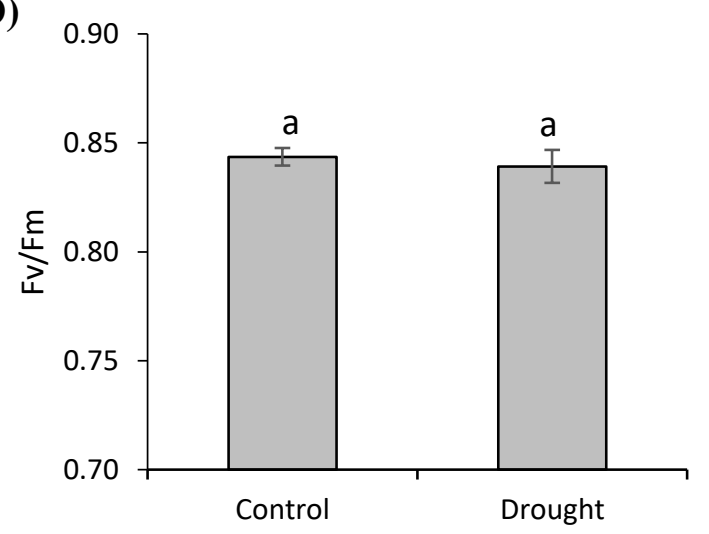

Figure 1. Relative growth rate (RGR; A), relative water content (RWC; B), leaf osmotic potential $\left(\Psi_{S} ; C\right)$ and chlorophyll fluorescence (Fv/Fm; D) of Borago officinalis L. grown under drought stress. Values followed by the same letter are not significantly different according to Fisher's LSD $(P<0.05)$. 


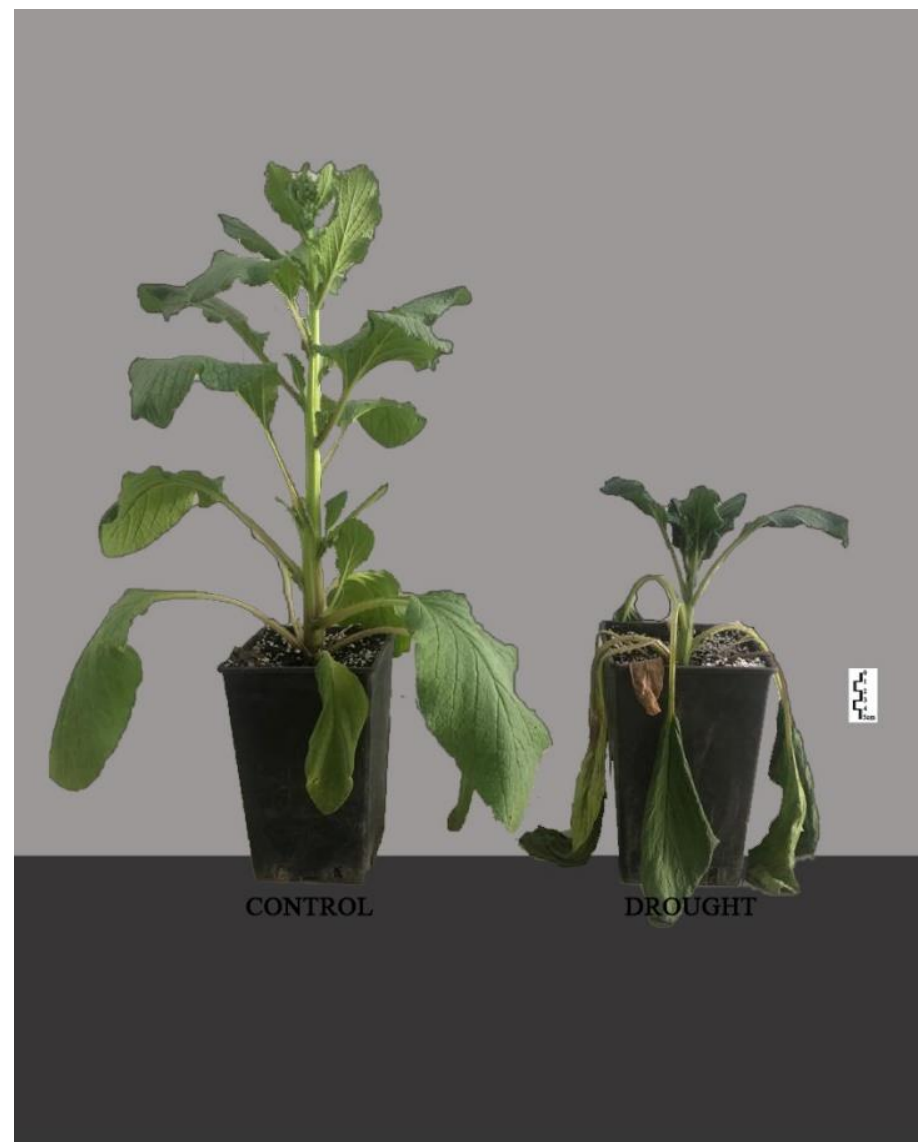

Figure 2. Morphological effects of drought stress on grown of Borago officinalis L. Scale bar, $5 \mathrm{~cm}$.

A)

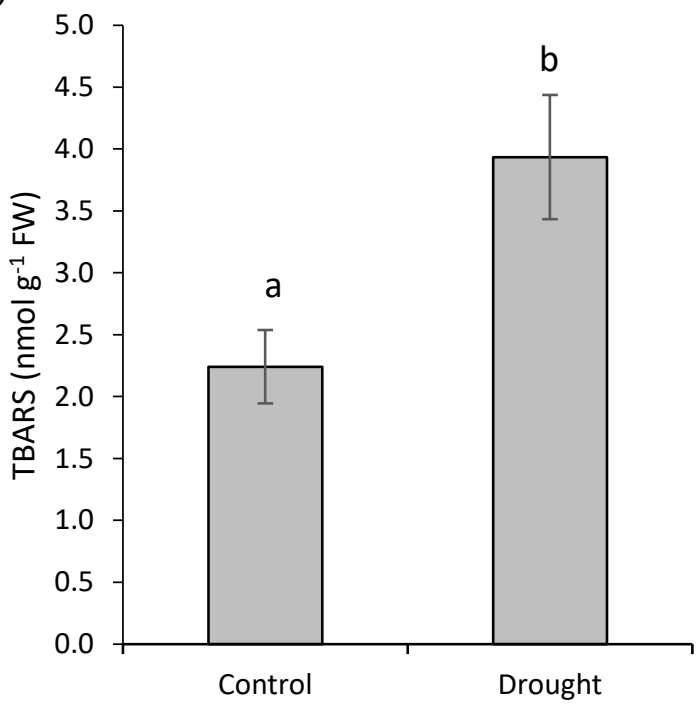

B)

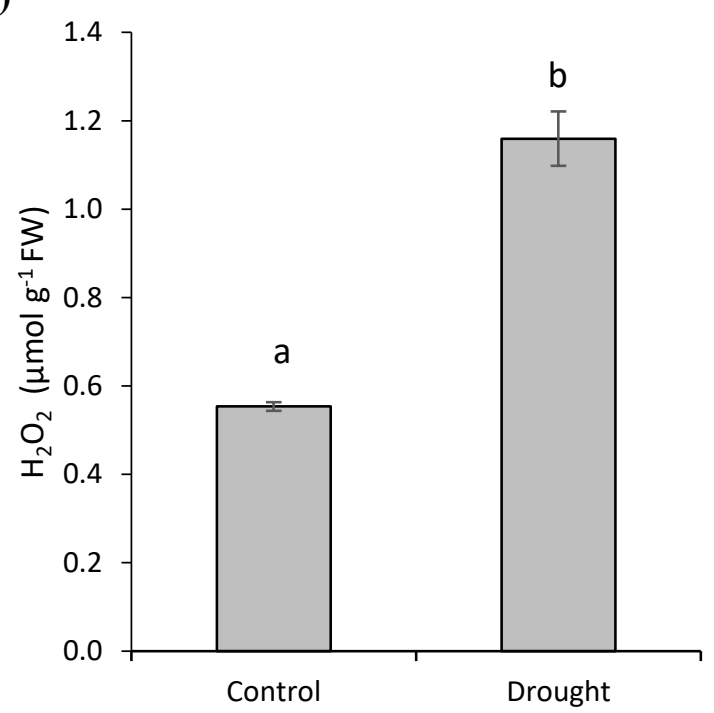

Figure 3. TBARS (A) and $\mathrm{H}_{2} \mathrm{O}_{2}$ (B) content of Borago officinalis $\mathrm{L}$. grown under drought stress. Values followed by the same letter are not significantly different according to Fisher's LSD $(P<0.05)$. 

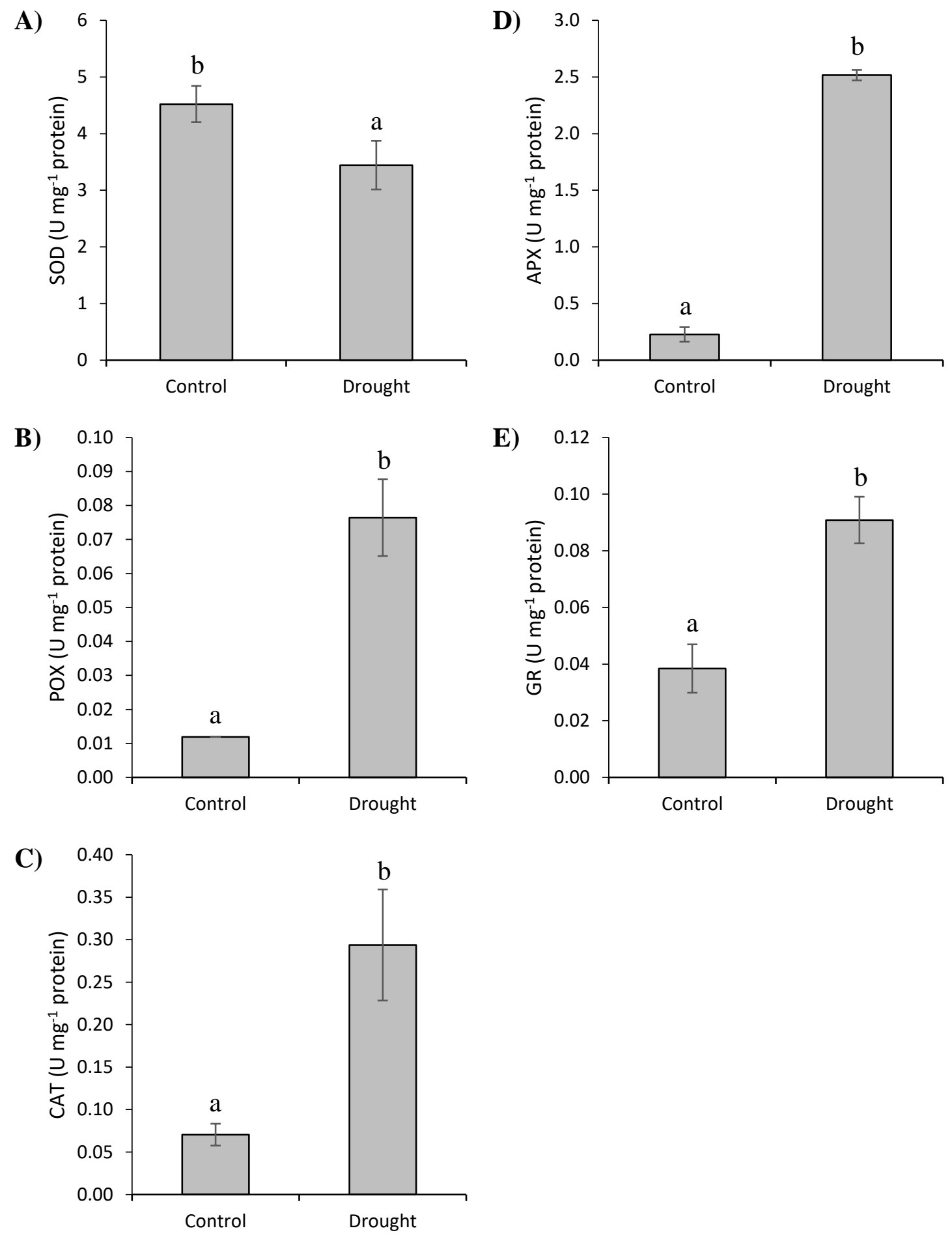

Figure 4. SOD (A), POX (B), CAT (C), APX (D) and GR (E) activities of Borago officinalis L. grown under drought stress. Values followed by the same letter are not significantly different according to Fisher's $\operatorname{LSD}(P<0.05)$.

\section{Conclusion}

Overall, in our study, drought stress induced responses in physiological and biochemical processes in Borago officinalis L. were obtained. Plant growth, leaf tissue RWC and osmotic potential were significantly reduced under drought, while lipid peroxidation and $\mathrm{H}_{2} \mathrm{O}_{2}$ accumulation were increased. Moreover, reduction in SOD activity and enhancement in POX, CAT, APX and $G R$ activities under drought suggests that the amount of antioxidant enzymes was not sufficient to prevent lipid peroxidation of membranes. In the future, the participation of antioxidants, phytohormones or other signal molecules required to be studied in Borago officinalis L. under drought stress. 
Conflict of Interest: There is no conflict of interest between the authors.

Author contributions: H.T. and E.E. designed the research, carried out the experiments, conducted statistical analyses and wrote the paper.

\section{References}

Abid, M., Ali, S., Qi, L.K., Zahoor, R., Tian, Z., Jiang, D., Snider, J.L., Dai, T. 2018. Physiological and biochemical changes during drought and recovery periods at tillering and jointing stages in wheat (Triticum aestivum L.). Scientific Reports, 8: 4615.

Aebi, H. 1984. Catalase in vitro. In: Methods in Enzymology. (eds) Colowick, S.P., Kaplan, N.O., Orlando: Academic Press, 114-121.

Amoah, J.N., Ko, C.S., Yoon, J.S., Weon, S.Y. 2019. Effect of drought acclimation on oxidative stress and transcript expression in wheat (Triticum aestivum L.). Journal of Plant Interactions, 14(1): 492-505.

Basu, S., Roychoudhury, A., Saha, P.P., Sengupta, D.N. 2010. Differential antioxidative responses of indica rice cultivars to drought stress. Plant Growth Regulation, 60: 51.

Beauchamp, C., Fridovich, I. 1971. Superoxide dismutase: improved assays and an assay applicable to acrylamide gels. Analytical Biochemistry, 44: 276-287.

Borowy, A., Chwil, M., Kapłan, M. 2017. Biologically active compounds and antioxidant activity of borage (Borago officinalis L.) flowers and leaves. Acta Scientiarum Polonorum Hortorum Cultus, 16(5): 169-180.

Borowy, A., Kapłan, M. 2020. Chemical composition and antioxidant activity of borage (Borago officinalis L.) seeds. Acta Scientiarum Polonorum Hortorum Cultus, 19(6): 79-90.

Bradford, M.M. 1976. A rapid and sensitive method for the quantization of microgram quantities of protein utilizing the principle of the protein-dye binding. Analytical Biochemistry, 72: 248-254.

Descamps, C., Quinet, M., Baijot, A., Jacquemart, A. 2018. Temperature and water stress affect plant-pollinator interactions in Borago officinalis (Boraginaceae). Ecology and Evolution, 8: 3443-3456.

Fernandes, L., Pereira, J.A., Saraiva, J.A., Ramalhosa, E., Casal, S. 2019. Phytochemical characterization of Borago officinalis L. and Centaurea cyanus L. during flower development. Food Research International, 123: 771-778.
Foyer, C.H., Halliwell, B. 1976. The presence of glutathione and glutathione reductase in chloroplasts: A proposed role in ascorbic acid metabolism. Planta, 133: 21-25.

Fracasso, A., Trindade, L., Amaducci, S. 2016. Drought tolerance strategies highlighted by two Sorghum bicolor races in a dry-down experiment. Journal of Plant Physiology, 190: 1-14.

Gill, S.S., Anjum, N.A., Gill, R., Yadav, S., Hasanuzzaman, M., Fujita, M., Mishra, P., Sabat, S.C., Tuteja, N. 2015. Superoxide dismutase-mentor of abiotic stress tolerance in crop plants. Environmental Science and Pollution Research, 22: 1037510394.

Hasanuzzaman, M., Bhuyan, M., Zulfiqar, F., Raza, A., Mohsin, S. M., Mahmud, J. A., Fujita, M., Fotopoulos, V. 2020. Reactive oxygen species and antioxidant defense in plants under abiotic stress: Revisiting the crucial role of a universal defense regulator. Antioxidants, 9(8): 681.

Hassan, N., Ebeed, H., Aljaarany, A. 2020. Exogenous application of spermine and putrescine mitigate adversities of drought stress in wheat by protecting membranes and chloroplast ultra-structure. Physiology and Molecular Biology of Plants, 26: 233245.

Heath, R. L., Packer, L. 1968. Photoperoxidation in isolated chloroplasts, I. kinetics and stoichiometry of fatty acid peroxidation. Archives in Biochemistry and Biophysics, 125: 189-198.

Hunt, R., Causton, D.R., Shipley, B., Askew, A.P. 2002. A modern tool for classical plant growth analysis. Annals of Botany, 90: 485488.

Ings, J., Mur, L.A., Robson, P.R., Bosch. M. 2013. Physiological and growth responses to water deficit in the bioenergy crop Miscanthus $\times$ giganteus. Frontiers and Plant Science, 4: 468-475.

Jaffel, K., Sai, S., Bouraoui, N.K., Ammar, R.B., Legendre, L., Lachâal, M., Marzouk, B. 2011. Influence of salt stress on growth, lipid peroxidation and antioxidative enzyme activity in borage (Borago officinalis L.). Plant Biosystems-An International Journal Dealing with all Aspects of Plant Biology, 145(2): 362-369.

Killi, D.; Raschi, A.; Bussotti, F. 2020. Lipid peroxidation and chlorophyll fluorescence of photosystem II performance during drought and heat stress is associated with the antioxidant capacities of C3 sunflower 
and C4 maize varieties. International Journal of Molecular Sciences, 21: 4846.

Liu, J., Lu, B., Xun, A.L. 2000. An improved method for the determination of hydrogen peroxide in leaves. Progress in Biochemistry and Biophysics, 27: 548-551.

Mattos, L.M., Moretti, C.L. 2015. Oxidative stress in plants under drought conditions and the role of different enzymes. Enzyme Engineering, 5: 1.

Mika, A., Lüthje, S. 2003. Properties of guaiacol peroxidase activities isolated from corn root plasma membranes. Plant Physiology, 132: 1489-1498.

Mittler, R. 2002. Oxidative stress, antioxidants and stress tolerance. Trends in Plant Science, 7: 405-410.

Mohajer, S., Taha, R.M., Ramli, R.B., Mohajer, M. 2016. Phytochemical constituents and radical scavenging properties of Borago officinalis and Malva sylvestris. Industrial Crops and Products, 94, 673-681.

Nakano, Y., Asada, K. 1981. Hydrogen peroxide is scavenged by ascorbate specific peroxidase in spinach chloroplasts. Plant and Cell Physiology, 22: 867-880.

Osakabe, Y., Osakabe, K., Shinozaki, K., Tran, L.S. 2014. Response of plants to water stress. Frontiers in Plant Science, 5: 86.

Ozfidan-Konakci, C., Yildiztugay, E., Kucukoduk, M. 2015. Protective roles of exogenously applied gallic acid in Oryza sativa subjected to salt and osmotic stresses: effects on the total antioxidant capacity. Plant Growth Regulation, 75(1): 219-234.

Rady, M.M., Belal, H.E.E., Gadallah, F.M., Semida, W.M. 2020. Selenium application in two methods promotes drought tolerance in Solanum lycopersicum plant by inducing the antioxidant defense system. Scientia Horticulturae, 266: 109290.

Sarker, U., Oba, S. 2018. Catalase, superoxide dismutase and ascorbate-glutathione cycle enzymes confer drought tolerance of Amaranthus tricolor. Scientific Reports, 8: 16496.

Sekmen, A.H., Ozgur, R., Uzilday, B., Turkan, I. 2014. Reactive oxygen species scavenging capacities of cotton (Gossypium hirsutum) cultivars under combined drought and heat induced oxidative stress. Environmental and Experimental Botany, 99: 141-149.

Shahnaz, G., Shekoofeh, E., Kourosh, D., Moohamadbagher, B. 2011. Interactive effects of silicon and aluminum on the malondialdehyde (MDA), proline, protein and phenolic compounds in Borago officinalis L. Journal of Medicinal Plants Research, 5(24): 5818-5827.

Sun, Y., Wang, C., Chen, H., Ruan, H. 2020. Response of Plants to Water Stress: A MetaAnalysis. Frontiers in Plant Science, 11, 978.

Torabi, F., Majd, A., Enteshari, S. 2015. The effect of silicon on alleviation of salt stress in borage (Borago officinalis L.). Soil Science and Plant Nutrition, 61(5): 788-798.

Torun, H. 2019. Combined salt and nickel stress Impact on ros generation and antioxidant enzymes activities of lemon balm (Melissa officinalis). Turkish Journal of Agricultural and Natural Sciences, 6(1): 97-105.

Zemmouri, H., Ammar, S., Boumendjel, A., Messarah, M., El Feki, A., Bouaziz, M. 2019. Chemical composition and antioxidant activity of Borago officinalis L. leaf extract growing in Algeria. Arabian Journal of Chemistry, 12(8): 1954-1963.

Zhou, Y., Lam, H.M., Zhang, J. 2007. Inhibition of photosynthesis and energy dissipation induced by water and high light stresses in rice. Journal of Experimental Botany, 58(5): 1207-1217. 